\title{
Validation of several species names in Hyacinthaceae
}

\author{
Mario Martínez-Azorín ${ }^{1,2}$ \& Manuel B. Crespo ${ }^{2}$ \\ 1 Institute of Plant Science, Karl-Franzens-University Graz, Holteigasse 6, 8010 Graz, Austria \\ 2 CIBIO (Instituto Universitario de la Biodiversidad), Universidad de Alicante, P.O. Box 99, 03080 Alicante, Spain \\ Author for correspondence: Mario Martinez-Azorin,mmartinez@ua.es \\ Dol http://dx.doi.org/10.12705/636.21
}

\begin{abstract}
Hyacinthaceae includes many taxa of hysteranthous or proteranthous plants, in which leaves and inflorescences are not coetaneous. Many herbarium sheets of such taxa, including type specimens, were prepared with samples gathered at different times to include as many vegetative and reproductive structures as possible to facilitate future identification. As a result of our taxonomic work being undertaken on several genera of the family, we found that holotypes of 14 taxa include different gatherings and are therefore not validly published, according to Art. 8.2 of the Melbourne Code. Validation of those names is effected in the same genera and ranks as they were first described, and a brief discussion is added for each case. Furthermore, four additional names are discussed in which a conclusive interpretation about invalid publication is not possible according to the available data, and hence their acceptance as valid names is here suggested.
\end{abstract}

Keywords Albuca; Asparagaceae; Drimia; Hyacinthaceae; nomenclature; Ornithogalum, Rhadamanthus; Scilloideae; Tenicroa; typification; Urginea

\section{口 INTRODUCTION}

Hyacinthaceae Borkh. (sensu APG, 2003) includes about 1000 species of bulbous plants, mainly distributed through Europe, Africa and south-west Asia, with a single small genus (Oziroe Raf.) in South America. It is alternatively treated as Asparagaceae subfam. Scilloideae Burnett (Chase \& al., 2009). Many taxa in the family include synanthous plants, in which leaves and flowers coexist together within a short period of the year, whereas entire genera and many species are hysteranthous or proteranthous, thus leaves and inflorescences are not coetaneous.

For that reason, collectors commonly harvest bulbs of Hyacinthaceae in a vegetative state, which later are cultivated in greenhouses until flowering and fruiting, a process that in some cases takes years. Once flowers and fruits are produced, herbarium sheets are carefully mounted to include all vegetative and reproductive structures facilitating identification. This practice, however, usually implies that many herbarium sheets are made by merging materials gathered at different times, since fresh leaves and inflorescences are not coetaneous. Some of those collections become later type specimens following taxonomic work.

According to the ICN (Melbourne Code; McNeill \& al., 2012), "publication on or after 1 January 1958 of the name of a new taxon of the rank of genus or below is valid only when the type of the name is indicated" (Art. 40.1), a condition that can be achieved "by reference to an entire gathering, or a part thereof, even if it consists of two or more specimens" (Art.
40.2), and assuming that a specimen is "a gathering, or part of a gathering, of a single species or infraspecific taxon made at one time, disregarding admixtures" (Art. 8.2). This applies to holotype, lectotype, or neotype, as stated in Art. 8.1.

Our recent taxonomic research on several genera of Hyacinthaceae (cf. Manning \& al., 2007; Martínez-Azorín \& al., 2007, 2010a, b, 2013a, b) has required the revision of numerous type materials collected mostly in the last two centuries. In the course of the revision of some South African groups we found that holotypes of some taxa include materials from different gatherings, which is contrary to the Melbourne Code, and hence they are not validly published. The strict application of Art. 8.2 will cause, in the case of plants where leaves and flowers are not produced simultaneously, some obligate nomenclatural changes, in particular in bulbous taxa. However, as long as the wording of the cited article stands unchanged, the current requirements of the Code must be complied with.

Accordingly, validation of 14 names in Hyacinthaceae is here effected by designation of new valid holotypes in the same genera and ranks as they were first described. Four additional cases are discussed in which current data do not allow a conclusive interpretation about invalid publication, and therefore acceptance is suggested here. Although the examples discussed below apply only to southern African taxa, they span a long period of time and affect a number of different authors. Therefore, the problem treated here could concern the general botanical community. On this respect, this particular issue with the Code could be a matter of discussion in future international botanical congresses.

Received: 22 Oct 2013 | returned for first revision: 27 Feb 2014 | last revision received: 4 Mar 2014 | accepted: 9 Mar 2014 | not published online ahead of inclusion in print and online issues || C International Association for Plant Taxonomy (IAPT) 2014 


\section{MATERIALS AND METHODS}

As part of our taxonomic work on southern African species of Hyacinthaceae, we found that the names discussed below were in need of valid publication. Type specimens were studied at $\mathrm{ABH}, \mathrm{BOL}, \mathrm{GRA}, \mathrm{K}, \mathrm{NBG}$ and SAM and images of type specimens from B, E, MO, NU and PRE were studied on JSTOR and Röpert (2000). Images of those types not available on line are shown in the figures.

\section{RESULTS AND DISCUSSION ${ }^{1}$}

\section{Taxa of Hyacinthaceae subfam. Ornithogaloideae Speta}

Albuca bruce-bayeri U.Müll.-Doblies, sp. nov. (U.Müll.Doblies in Feddes Repert. 105: 366. 1994, nom. inval.) - Holotype: SOUTH AFRICA. Cape. - 3321AD (Ladismith): Little Karoo, ca. $3 \mathrm{~km}$ E of Ladismith, road side, 23 May 1979, Bruce-Bayer 1756//ex cult. BTU 2930 (B barcode B 100185586 [digital image!]: the specimen with flowers and leaves on the right hand side, bearing the handwritten note "19.09.1986 ex cult. BTU/3").

Albuca bruce-bayeri was described by Müller-Doblies (1994) based on bulbs collected in 1979 by M.B. Bayer (coll. num. 1756) E of Laingsburg, in the Little Karoo in South Africa. These bulbs were later grown in BTU under the garden number 2930. Type material was said to be deposited at B, BOL, BR, BTU, E, GRA, K, M, MO, PRE (holotype), S, STE, WAG, WIND, and Z. Although no collection date was indicated in the protologue, the image of an isotype (B 10 0185586; http://herbarium.bgbm.org/object/B100185586) was published by Müller-Doblies (2006), which showed further data on a label: "ca. $3 \mathrm{~km}$ E of Ladismith, road side, 23. 05.1979, leg.: Bruce Bayer 1756//ex cult. BTU 2930”; on it were three additional handwritten dates "3: 19.9.1986 / 3: 26.5.1985 / 12: 27.9.1992". Furthermore, the herbarium sheet includes five leaves at the bottom with the following

1 Nomenclature Editor's Note: Unlike the authors, I am not convinced that the following names were not validly published at their original places of publication: Albuca hallii, Albuca unifoliata, Ornithogalum autumnulum, Drimia montana, Rhadamanthus involutus, and Urginea saniensis. However, I acknowledge that distinguishing between a single gathering and multiple gatherings can be subject to multiple interpretations. In the ICN (McNeill \& al., 2012), the term gathering is used in several places (see Art. 8.2, 8.3+fn.2, 9.5, 9.17, 40.2+N.1, 40.3+N.2) and is included (but not formally defined) in the glossary. I anticipate that this issue will be discussed at the upcoming nomenclature section meeting in Shenzhen in 2017, proposals to amend Art. 40 Note 2 (Li \& Guan in Taxon 63: 693. 2014) and amend the entry for gathering (Zhu in Taxon 63: 1145-1146. 2014) already having been published. The problem of phantom holotypes discussed in this manuscript and elsewhere (Bandyopadhyay \& al. in Phytotaxa 163: 239-240. 2014) should also generate discussion at Shenzhen. - G.M. handwritten note "26.05.1985 ex cult. BTU/3" as well as two plants in flower with leaves (lacking bulbs), each one with a handwritten note next to it (the left hand side one "27.09.1992 ex cult. BTU/12" and the right hand side one "19.09.1986 ex cult. BTU/3"). A dissected flower is also located at the upper left hand corner with an additional handwritten note "2930/3 (MBB 1756) Albuca bruce-bayeri 2.10.83". It is evident therefore that the type material of this species includes several pieces of plants collected at different times, which is contrary to Art. 8.2 of the Code, and therefore the validation of this species name is required. The holotype is not yet deposited at PRE (R.R. Klopper, pers. comm.), as is the case for many of the numerous new taxa described in recent times by Ute Müller-Doblies and Dietrich Müller-Doblies. This also applies to most of the isotypes not yet extant in any South African or other herbaria referred to in the protologue of A. brucebayeri. Therefore, we here select a fragment on B 100185586 as holotype of this name.

Albuca hallii U.Müll.-Doblies, sp. nov. (U.Müll.-Doblies in Feddes Repert. 105: 366. 1994, nom. inval.) - Holotype: SOUTH AFRICA. Cape. - 3119DA (Calvinia): Kareeboomfontein, S of Calvinia, gravel and shale, 6 Aug 1986, U. \& D. MüllerDoblies 86044g//ex cult. BTU 6727 (B barcode B 100185585 [digital image!]: the inflorescence on the right hand side, with the handwritten note "14.8.1991 ex cult /1").

Albuca hallii was described by Müller-Doblies (1994) based on plants collected on Farm Kareeboomfontein, S of Calvinia in South Africa by U. \& D. Müller-Doblies (holotype: PRE; isotypes: B, BOL, BTU, GRA, K, M, MO, S, STE, WIND, $\mathrm{Z})$. No collecting date was indicated in the protologue, but the image of an isotype (B 10 0185585; http://herbarium.bgbm.org/ object/B100185585) was published by Müller-Doblies (2006) and it includes further data: "06.08.1986, ..., leg.: U. \& D. MüllerDoblies $86044 \mathrm{~g} / \mathrm{/ex}$ cult. BTU 6727"; with a handwritten note giving two additional dates “14. 08.1991/1 / 1.08.1992/2”. Moreover, the herbarium sheet includes two unconnected inflorescences and 10 leaves connected to the neck of the bulb. The leaves bear the following handwritten note "wild 6. 8.1986". The large inflorescence on the right hand side shows the following handwriting "14.8.1991 ex cult /1" and the upper and smaller inflorescence is annotated "ex cult. $/ 2$ 01.08.1992". It is evident therefore that the type of this species includes several portions of plants collected at different times and therefore validation of this species name is needed. As in the case above, Müller-Doblies's holotype has not yet been deposited at PRE (R.R. Klopper, pers. comm.) nearly 20 years after its description, and therefore we select as holotype of $A$. hallii a fragment on B 100185585.

Albuca unifoliata G.D.Rowley, sp. nov. (G.D.Rowley in Ashingtonia 2: 55. 1975, nom. inval.) - Holotype: SOUTH AFRICA, at Eenriet near Steinkopf, 15 Aug 1971, G.D. Rowley GR329 (K barcode K000365545!: the bulb with one leaf on the left hand side of the voucher).

Albuca unifoliata was described by Rowley (1975) from bulbs collected 15 August 1971 together with Harry Hall at Eenriet, near Steinkopf, South Africa. In the protologue only 
a partial reference to the type is made "Holotypus GR329 in Herb. Kew (K.)", without further explicit data. However, beside the original description further information was provided by Rowley: "Back home in England the club-like leaf withered and an inflorescence grew up to take its place. Each year since then one or the other has appeared, never the two together", and also "Leaf solitary, [...] apparently never borne at the same time as the inflorescence" or "Scape stiffly erect, leafless". Those comments accompany two photographs showing several bulbs in both states, either with leaves or flowers. Indeed, it is reliably a proteranthous species in which leaves are produced in August, whereas flower anthesis occurs in October, when leaves are completely withered and even absent, as shown by Obermeyer (1978) from materials belonging to the original collection forwarded to her by H. Hall. The designated holotype (K000365545; http://plants.jstor.org/specimen/k000365545) includes diverse pieces under the same collection number: (1) two bulbs with inflorescences, lacking leaves; (2) five leaves with bulbs lacking inflorescences; and (3) an envelope containing ripe capsules and seeds. As stated by the author himself, leaves and inflorescences were not coetaneous, and therefore the materials in Rowley's holotype evidently came from different gatherings. As this conflicts with Art. 8.2, validation of this species name is therefore required, and a fragment on K000365545 is selected here as holotype.

Ornithogalum autumnulum U.Müll.-Doblies \& D.Müll.Doblies, sp. nov. (U.Müll.-Doblies \& D.Müll.-Doblies in Feddes Repert. 107: 511. 1996, nom. inval.) - Holotype: SOUTH AFRICA. SW Cape. - 3118 CB (Vanrhynsdorp): Farm "Liebendal", $10 \mathrm{~km}$ N of Vredendal, $100 \mathrm{~m}$, solitary on open spaces in undisturbed sandveld, 4 Jun 1974, H. Hall 4531 (PRE no. 0531616-1 [digital image!]: the specimen with bulb, leaves and an inflorescence with one opened flower, on the upper left corner of the sheet). - For image of holotype, see Fig. 1. Additional data on the type material procedence taken from the isotype NBG00102138.

Ornithogalum autumnulum was described by MüllerDoblies \& Müller-Doblies (1996), and later transferred to Coilonox by Speta (2001), a change accepted by MartínezAzorín \& al. (2011). A herbarium collection made by Harry Hall (coll. num. 4531) from Farm Liebendal, near Vredendal in South Africa, was selected as type (holotype: PRE; isotypes: B, BTU, K, NBG) by Müller-Doblies \& Müller-Doblies (1996). The cited holotype (PRE 0531616) is peculiar, since it is formed by two herbarium sheets under the collection $H$. Hall 4531, one with plants and the other with a photograph of plants in cultivation. The first sheet (PRE 0531616-1) includes three plants with bulbs and leaves, one of them in flower and another with ripe capsules together. Moreover, two dissected flowers mounted on small cards are attached to the sheet. On the label of this sheet one can read "Anno 1973", "flowered PRE 12.4.1979", and "Gr Nr. 20130". It is worth mentioning that the label was annotated "glandulosum Oberm." by hand, to replace the original "Ornithogalum n. sp. (subgenus Osmyne)". The second sheet (PRE 0531616-2) includes a photograph taken by A. Romanowski of several plants starting to flower in a single pot, and the label indicates "Flowered PRE 22.3.1979 ex Kirstenbosch, Liebendal. Young plants" and also under the "Garden No 20130". As several materials and dates of different gatherings are indicated under the collection H. Hall 4531 in the cited Müller-Doblies's holotype at PRE, this is in conflict with Art. 8.2, and therefore validation of this species name is necessary. The specimen on the upper left side of the sheet PRE 0531616-1 is therefore selected here as holotype of $O$. autumnulum.

\section{Taxa of Hyacinthaceae subfam. Urgineoideae Speta}

Drimia cochlearis Mart.-Azorín, M.B.Crespo \& A.P.Dold, sp. nov. (Mart.-Azorín, M.B.Crespo \& A.P.Dold in Syst. Bot. 38: 334. 2013, nom. inval.) - Holotype: SOUTH AFRICA. Western Cape, ca. $11 \mathrm{~km} \mathrm{SW}$ of Calitzdorp, Gamkaberg Nature Reserve (former Groenefontein Nature Reserve), $408 \mathrm{~m}, 33^{\circ} 37^{\prime} 16^{\prime \prime} \mathrm{S}, 21^{\circ} 38^{\prime} 08^{\prime \prime} \mathrm{E}$, 29 Sep 2011, M. Martínez-Azorín, A.P. Dold, J. Vlok \& A. Martinez-Soler MMA941 (GRA!: the bulb with leaves).

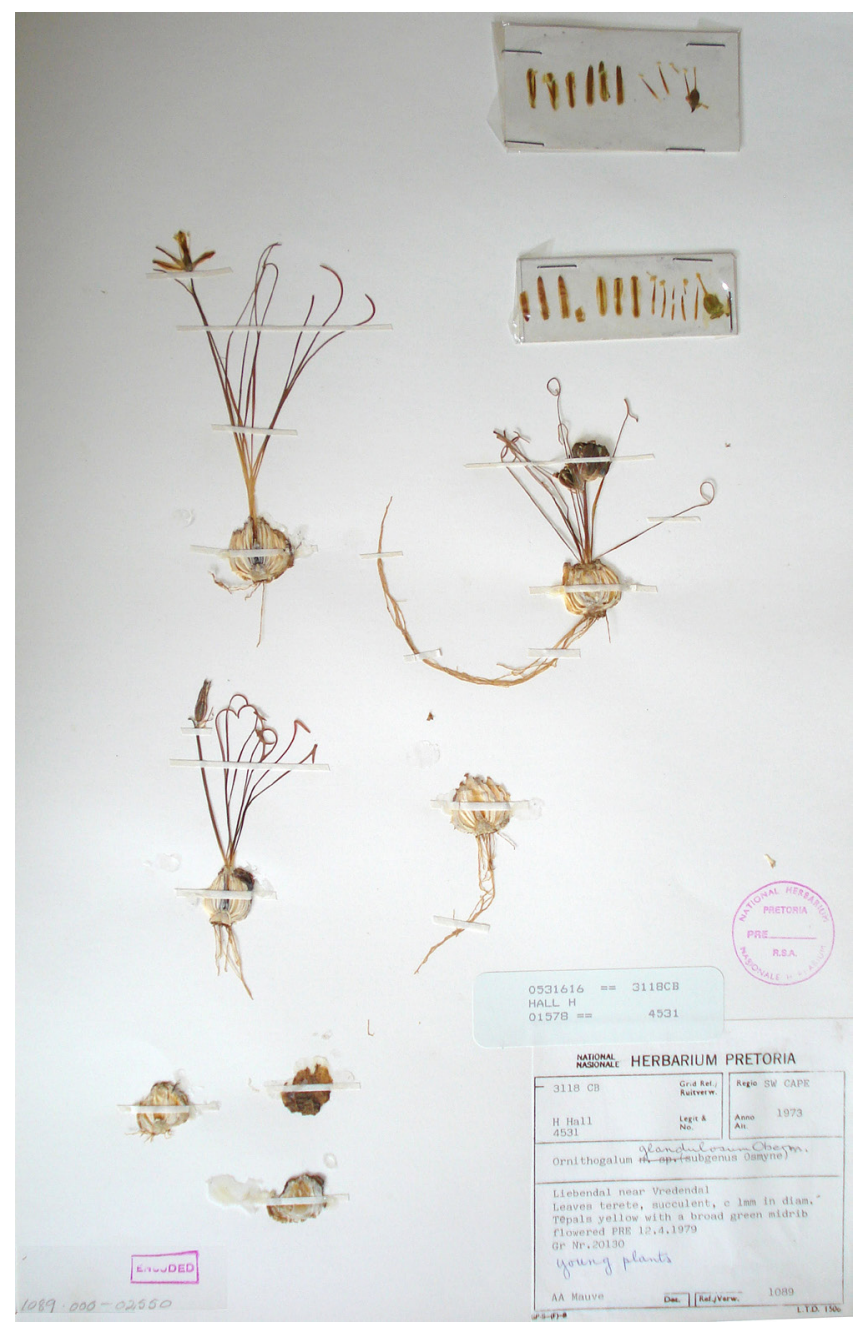

Fig. 1. Holotype of Ornithogalum autumnulum U.Müll.-Doblies \& D. Müll.-Doblies sp. nov. (PRE 0531616-1: the specimen with bulb, leaves and an inflorescence with one opened flower, on the upper left corner of the sheet). 
Drimia cochlearis was recently described by MartínezAzorín \& al. (2013a). The authors selected as the type of the new species a herbarium collection including plants from Gamkaberg Nature Reserve, SW of Calitzdorp in South Africa, explicitly indicating that bulbs with leaves from wild plants were taken on 29 September 2011 and the flowers were obtained ex hort. on 28 January 2012 in Grahamstown. This fact contradicts Art. 8.2, and therefore validation of this species name is required. A fragment on the sheet M. Martinez-Azorin \& al. MMA941 at GRA is selected here as the holotype.

Drimia ligulata J.C.Manning \& Goldblatt, sp. nov. (J.C. Manning \& Goldblatt in Bothalia 37(2): 186. 2007, nom. inval.) - Holotype: SOUTH AFRICA. Zebra Kop, Piketberg mts., in shallow soil at rocky summit, $4700 \mathrm{ft}$., 23 May 1948, flowered at B.H., Flor. Dec-Jan. $1948+1949$, E. Esterhuysen 14487 (BOL barcode 150154!: the bulb with three leaves on the lower left hand side corner of the sheet).

Drimia ligulata was described by Manning \& Goldblatt (2007). These authors selected the collection E. Esterhuysen 14487 (BOL 150154; http://plants.jstor.org/specimen/ bol150154), from the Piketberg mountains in South Africa, as the holotype of their new species. In the protologue the following dates were indicated "23 May 1948 (fl Dec-Jan 1948 and 1949)" and the leaves were said to be "dry and withered or emergent at flowering". Moreover, the study of the label of the type specimen provides further data: "Bulbs collected 23. 5. 48, flowered at B.H." and "Flor. Dec-Jan. $1948+1949$ ". The herbarium sheet includes several fragments: (1) eight bulbs with well-developed leaves; (2) eight unconnected and withered leaves; and (3) eight unconnected inflorescences, most of them in full flower but one in fruit with ripe capsules and seed. According to the available data (cf. Manning \& Goldblatt, 2007) bulbs with fresh leaves are found in September-October, whereas inflorescences develop in December-January. Based on the information provided here, the most realistic interpretation is that the sheet includes material gathered at different times and therefore the species name is not validly published. A fragment on the sheet BOL 150154 is designated as the holotype of D. ligulata.

Drimia montana A.P.Dold \& E.Brink, sp. nov. (A.P.Dold \& E.Brink in Bothalia 36(1): 64. 2006, nom. inval.) Holotype: SOUTH AFRICA. Eastern Cape Province, 3326AD, The Hoek (Farm), Groot Winterberg (Spring Valley 3326AD), Tarkastad, exposed sandstone ledge on steep west facing slope at foot of cliff scree, $33^{\circ} 20^{\prime} 15^{\prime \prime} \mathrm{S}$ $26^{\circ}, 2150 \mathrm{~m}, 1$ Jan 2004, T. Dold \& M. Cocks 4633 (GRA barcode GRA0000460-0!: the lowermost plant with a bulb and an inflorescence including ca. eight flowers (one of them in full flower) located in the upper part from the diagonal line).

Drimia montana was described by Dold \& Brink (2006) from the Eastern Cape province of South Africa. In the original description, the holotype (GRA0000460-0; http://plants .jstor.org/specimen/gra0000460-0) was said to be collected on The Hoek farm, in the Groot Winterberg on 1 January 2004.
However, the sheet at GRA shows material explicitly gathered at different times. First, plants in flower and fruit lacking leaves were "Pressed in December at time of collection" (though corrected to January by A.P. Dold 08/10/2014; A.P. Dold pers. comm.), and are placed on the upper half of the sheet. Second, and separated by a solid pencil line, leafy bulbs are placed on the lower half on the same herbarium voucher, which correspond to "Plants pressed in March 2004 after dormancy". The existence of plants collected at two different times in Dold \& Brink's holotype makes publication of this species invalid. Therefore, a fragment on the sheet T. Dold \& M. Cocks 4633 (GRA00004600 ) is selected here as the holotype of D. montana.

Drimia vermiformis J.C.Manning \& Goldblatt, sp. nov. (J.C. Manning \& Goldblatt in Bothalia 37(2): 184. 2007, nom. inval.) - Holotype: SOUTH AFRICA. Cape, Clanwilliam (3218BB), Clanwilliam Dam, Picnic site by N7 near wall, 3 Aug 1987, Ex hort. Inflorescence 11/10/1988, Leaf 2/5/91, P.L. Perry 3587 (NBG barcode NBG0149721-0!: the leaf). The type of Drimia vermiformis was selected by Manning \& Goldblatt (2007) as "P.L.Perry 3587 (NBG, holo.)". In the protologue, two dates are included in the collection of the holotype "03 August 1987 (fl. in cult. 11 October 1988)". Moreover, on the herbarium label of the holotype (NBG0149721-0; http:// plants.jstor.org/specimen/nbg0149721-0), the collecting date is 3 August 1987 but it is indicated "Ex hort. Inflorescence 11/10/1988" and "Leaf 2/5/91". Furthermore, in the morphological description of the new species it is said that "Leaf dry and withered at flowering". It is clear that the flowering stems, leaf and bulbs present in Manning \& Goldblatt's holotype were gathered at different times, as indicated explicitly on the label, and therefore the description of this species needs to be validated. Accordingly, a fragment on the sheet NBG0149721-0 is selected here as holotype of the name.

Rhadamanthus involutus J.C.Manning \& Snijman, sp. nov.(J.C. Manning \& Snijman in Novon 9: 113. 1999, nom. inval.) - Holotype: SOUTH AFRICA. 3119AC (Calvinia), Bokkeveld plateau, farm Arendskraal, $\mathrm{W}$ of Nieuwoudtville, in humus-rich soil amongst exposed sandstone sheets, Leaves from field 3/9/96, Flowers from field 20/12/95, D. Snijman $\& J$. Manning 1525 (NBG barcode NBG0158587-0!: the inflorescence on the upper left hand side corner). - For image of holotype, see Fig. 2.

Rhadamanthus involutus was described by Snijman \& al. (1999) from the Bokkeveld Escarpment in South Africa. In the protologue, the collection Snijman \& Manning 1525 was selected as the type (holotype: NBG; isotypes: K, MO, PRE), and it was said to be collected on 20 December 1995. However, the herbarium labels of the holotype clearly state: "Leaves from field 3/9/96" and "Flwrs from field 20/12/95". Also, both the label of the type and the protologue indicate that the species is hysteranthous. The holotype (Snijman \& Manning 1525, NBG) includes four bulbs with leaves, four unconnected inflorescences and four unconnected and withered leaves, fully agreeing with the two different gatherings explicitly indicated on the label. Provided that the flowering stems and leafy bulbs were 
gathered at different times, the validation of this species is necessary. Therefore, a fragment on the sheet Snijman \& Manning 1525 (NBG) is selected here as the holotype of the name.

Rhadamanthus karooicus Oberm., sp. nov. (Oberm. in Bothalia 13(1-2): 138. 1980, nom. inval.) - Holotype: SOUTH AFRICA. Cape, 3320BB (Montagu), Laingsburg, farm Keurfontein, Flowered at BRI, Dec. 1974, in leaf May 1975, J. van Zanten sub PRE45560 (PRE barcode PRE0240643-1 [digital image!]: the plant with bulb, withered leaves and inflorescence located on the left hand side of the sheet).

Rhadamanthus karooicus was described by Obermeyer (1980) from Farm Keurfontein, near Laingburg in South Africa. The collection $J$. van Zanten sub PRE45560 (PRE) was selected as the holotype. In the protologue no indication of the collection date was supplied. However, that collection includes two herbarium sheets. Sheet 1 (PRE0240643-1; http://plants .jstor.org/specimen/pre0240643-1) bears bulbs with withered leaves and inflorescences, and labelled "Flowered at BRI, Dec. 1974". Sheet 2 (PRE0240643-2; http://plants.jstor.org/specimen/ pre0240643-2) includes, under the same collection number, bulbs with leaves labelled "Laingsburg, in leaf May 1975". Furthermore, the protologue indicates "Folia 4-6 hysteranthia". It

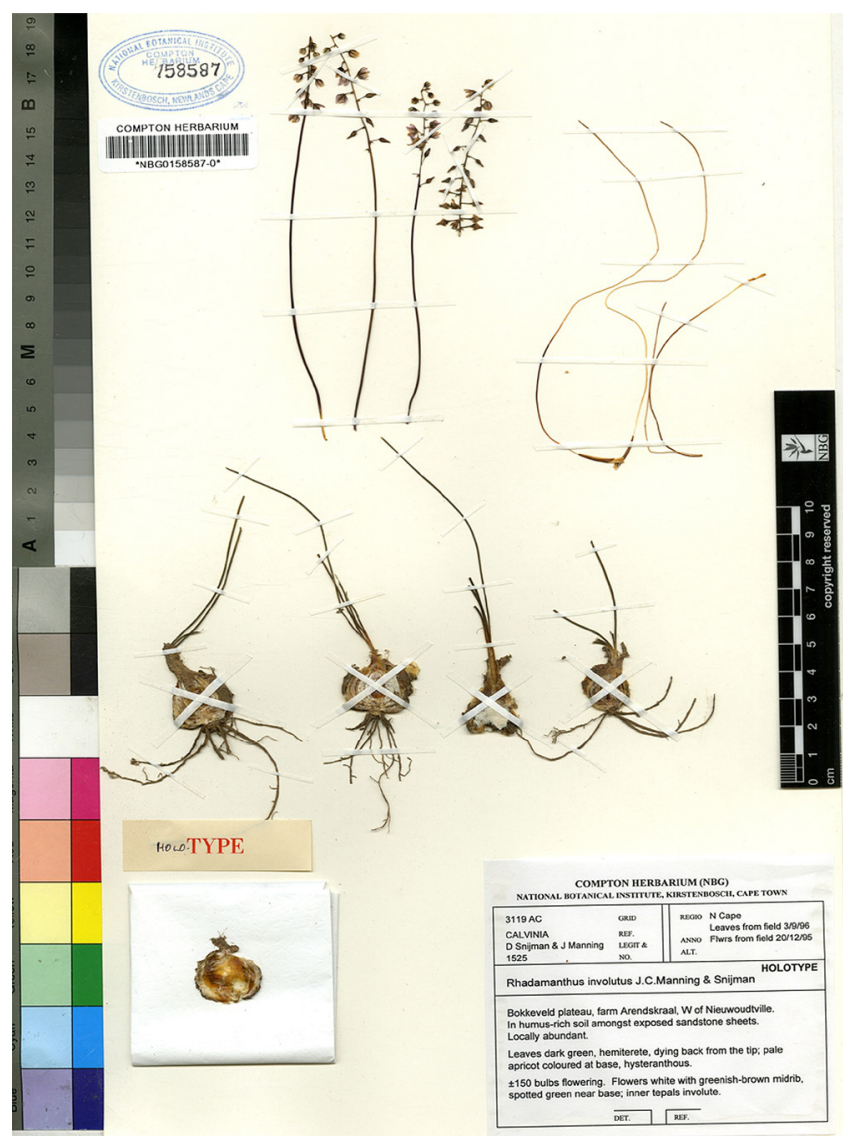

Fig. 2. Holotype of Rhadamanthus involutus J.C.Manning \& Snijman sp. nov. (D. Snijman \& J. Manning 1525, NBG: the inflorescence on the upper left hand side corner). is evident that Obermeyer's holotype includes two gatherings from different dates, and therefore this species name is in need of validation. The gathering in PRE0240643-1 is here designated as the holotype of $R$. karooicus.

Rhadamanthus montanus B.Nord., sp. nov. (B.Nord. in Bot. Not. 123: 162. 1970, nom. inval.) - Holotype: SOUTH AFRICA. South-Western Region, Stellenbosch Div.: Jonkershoek Twins, ledges, N.E. side, 3-4000 ft., Flor. 12 Feb. Anno 1945, Leaves 10 Nov. 1945, E. Esterhuysen 11456 (BOL barcode BOL140331!: the bulb with withered leaves bearing two inflorescences, on the upper right hand corner of the sheet).

Rhadamanthus montanus was described by Nordenstam (1970), with the type indicated as follows: "Orig. coll.: Esterhuysen 11456, Cape Province, Stellenbosch Div., Jonkershoek Twins, ledges, NE side, 3000-4000 ft, 12.II. 1945, leaves added VI. 1945 (BOL holotype, K, NBG)". The label of the holotype (BOL140331; http://plants.jstor.org/specimen/bol140331) corroborates this fact: "Flor. 12 Feb. Anno 1945" and "Leaves 10 Nov. 1945". Five bulbs with leaves are located on the lower part of the herbarium collection and several unconnected inflorescences, including one bulb with two inflorescences and withered leaves are placed on the upper part. This supports the fact that two different gatherings at different times form Nordenstam's holotype. Therefore, this species was not validly published and is validated here by designation of one fragment on BOL140331 as the holotype.

Rhadamanthus namibensis Oberm., sp. nov. (Oberm. in Bothalia 13(1-2): 137. 1980, nom. inval.) - Holotype: S.W. Africa [NAMIBIA]. 2716DA (Witpütz): WitpützSuid, $1 \mathrm{~km}$ SE of Police Station, W. Giess 13781 (PRE barcode PRE0488688-1 [digital image!]: the inflorescence in two pieces).

Rhadamanthus namibensis was described by Obermeyer (1980) with no date indication in the type designation: "S.W. Africa, 2716 (Witpütz): Witpütz-Suid, 1 km S.E. of Police Station, (-DA), Giess 13781 (PRE, holo.; WIND)". However, the following information was provided in the protologue: "The type flowered in October 1977; capsules with ripe seeds were produced in November; the new leaves emerged in January and reached maturity in March 1978". Obermeyer's holotype at PRE includes two herbarium sheets under the collection Giess 13781 (PRE0488688-1 and PRE0488688-2). The labels of both sheets show the following data "Anno 30.9.1975" and "Flowered in nursery at Pretoria in Oct. 1976. Garden no. 20443". The herbarium sheet number one (PRE0488688-1; http://plants.jstor.org/specimen/pre0488688-1) includes one inflorescence in two pieces, dissections of three flowers, and several unconnected bulbs scales and leaves. The herbarium sheet number two (PRE0488688-2; http://plants.jstor .org/specimen/pre0488688-2) shows a single dissected bulb with three attached leaves under the same collection $W$. Giess 13781 and an identical herbarium label. Furthermore, two additional isotypes, not cited in the protologue, are extant at $\mathrm{K}$ and M (K000257234; http://plants.jstor.org/specimen/k000257234 
and M-0107238 http://plants.jstor.org/specimen/m0107238) under the collection number Giess 13781. The isotype at K includes a single inflorescence and the herbarium label provides further information: "capsules \& seeds collected November 1977 from plant painted for Flow. Plants". The isotype at M shows a single plant with a dissected bulb and one inflorescence attached, and the label (under WIND label) indicates "W. Giess 13781 (= M. \& G. 32570)", "fl. i. hort. 14.10.1977" and "Farm Witpütz Nord: LUS 22. [...], gesammelt 16.8.1976. Blüht im Garten W. Giess, Windhoek". Considering all the data provided above, and in particular the sentence in the protologue about flowers and leaves of type materials being not coetaneous, it is evident that Obermeyer's holotype at PRE includes fragments collected at different times. This is congruent with figure 4 in the protologue in which bulbs with fresh flowers bear no flowering scapes, whereas a bulb with a flowering scape shows leaves completely withered. Therefore, the type material of $R$. namibensis contradicts Art. 8.2, and the description of this species name is validated here by designating a fragment on K000257234 as the holotype.

Rhadamanthus platyphyllus B.Nord., sp. nov. (B.Nord. in Bot. Not. 123: 172. 1970, nom. inval.) - Holotype: SOUTH AFRICA. Cape, Clanwilliam, below Cederberg Tafelberg, in stony or shallow sand on rocky slope below shale band, 3500-4000 ft., Flor. 16 Dec. 1950, grown at B.H. for leaves, Apr. 1951, E. Esterhuysen 18135 (BOL barcode BOL140333!: the bulb with two leaves at the bottom left hand side corner of the sheet).

Rhadamanthus platyphyllus was described by Nordenstam (1970) who referred to the type as follows: "Orig. coll.: Esterhuysen 18135, Cape Province, Clanwilliam Div., Cederberg Tafelberg, 3500-4000 ft, 16.XII. 1950, leaves added IV. 1951 (BOL holotype)". Furthermore, the holotype (BOL140333; http://plants.jstor.org/specimen/boll40333) comprises a single sheet in which numerous plants with leaves, flowers or fruits are included. The label of the holotype states: "Flor. 16 Dec. 1950" and "Grown at B.H. for leaves, Apr. 1951". As in previous cases, it is evident that the Nordenstam's holotype comprises plants from different gatherings, and therefore the validation of this species name is required. A sample on BOL140333 is here selected as the holotype of $R$. platyphyllus.

Urginea saniensis Hilliard \& B.L.Burtt, sp. nov. (Hilliard \& B.L.Burtt in Notes Roy. Bot. Gard. Edinburgh 42: 253. 1985, nom. inval.) - Holotype: LESOTHO. Top of Sani Pass, ca. 9500 ft., in soil in cracks of rock, 6 Nov 1973, O.M. Hilliard \& B.L. Burtt 7102 (E barcode E00193964 [digital image!]: the eight bulbs with both flowers and leaves enclosed into the envelope placed in the central part of the sheet).

Urginea saniensis was described by Hilliard \& Burtt (1985) from the top of Sani Pass in the Drakensberg, Lesotho. In the protologue, the type was selected as: "Lesotho, top of Sani Pass, c.9500ft, in soil in cracks of rocks, 6 xi 1973, Hilliard \& Burtt 7102 (E holo., NU iso.)". Furthermore, it was said that "Leaves, capsules and seeds were described from plants that flowered in the Royal Botanic Garden, Edinburgh". The label of the cited holotype (E00193964; http://plants.jstor.org/speci men/e00193964) shows "Date 6 xi 1973" and includes two envelopes. The one in the central part of the sheet encloses eight bulbs with flowers and leaves that would have been collected the date marked on the label, whereas the one in the upper left hand side corner is annotated "HuB 7102, 73 1954. / fruit coll. RBGE 18/vii/87" and includes unconnected leaves and ripe capsules. It is evident therefore that Hilliard \& Burtt's holotype consists of plants gathered at different times and the species name in not validly published. Accordingly, the gathering comprising eight bulbs into the envelop in the central part of E00193964 is designated here as holotype of $U$. saniensis.

\section{Additional comments on other species descriptions}

Drimia pulchromarginata J.C.Manning \& Goldblatt in Bothalia 37(2): 185. 2007 - Holotype: SOUTH AFRICA. Cape, 3018AA (Kamiesberg), Farm Draaiklip, sandy flats, C.H. Stirton 9226 (NBG barcode NBG0127044-0!).

The holotype (NBG0127044-0; http://plants.jstor.org/ specimen/nbg0127044-0) of Drimia pulchromarginata designated by Manning \& Goldblatt (2007) includes four bulbs with a single leaf each and two unconnected inflorescences. In the protologue, it was said "31 October 1983 (fl. in cult.)" and "Typically $2-4$ leaves are produced, and the plants remain evergreen if conditions permit". However, only the date "31-101983 " is annotated on the label of the type sheet. As the plants in the type specimen flowered in cultivation, it is not possible to ascertain if such herbarium collection was made at different times, since possibly that cultivated material could bear leaves and flowers at the same time. Therefore, we consider here that this species name was validly published in 2007.

Ornithogalum diluculum Oberm. in Bothalia 12(2): 371. 1978 - Holotype: SOUTH AFRICA. Cape, 3320AD (Montagu), Bloutoring, Sep 1974, Flowered Sept.-Oct. 1976, A.A. Mauve \& I. Oliver sub PRE57046 (PRE barcode PRE0475686-0 [digital image]!).

Ornithogalum diluculum was described by Obermeyer (1978) and later transferred to Coilonox by Speta (2001). In the protologue, no indication of collection date was made when designating the type, but later it was added "The bulbs were in leaf when collected in September 1974; they flowered at the Botanical Research Institute in September 1976." Moreover, the label of the holotype (PRE0475686-0; http://plants.jstor.org/specimen/ pre0475686-0) corroborates these data "Anno Sept. 1974" and "Flowered Sept.-Oct. 1976". The herbarium collection of the holotype includes different fragments: (1) one bulb with a scape with ripe capsules; (2) an unconnected ripe capsule; (3) five portions of unconnected leaves; (4) a dissection of one flower mounted on a separate card, and (5) several seeds in an envelope. From the plant portions present in the holotype, it is very improbable that all those materials were collected at one time. However, it is also not possible to ascertain if all these plant portions were present at a single time in different individuals, due to cultivation 
conditions. Moreover, the photograph in figure 54 cited in the protologue shows a flowering plant with two leaves, one of them decaying and the other just developing. This fact demonstrates that leaves can be coetaneous with flowering stems and perhaps later also with fruits in different plants under cultivation. Therefore we consider that this name was validly published.

Tenicroa nana Snijman in S. African J. Bot. 51: 284. 1985 - Holotype: SOUTH AFRICA. Cape, 3018AC, Kamiesberg, on slopes of the Rooiberg, $1300 \mathrm{~m}$, fl. ex Kirstenbosch 26 Nov. 1980, D. Snijman 292 (NBG barcode NBG0123648-0!; isotype: PRE barcode PRE0665215-0!) - For image of holotype, see Fig. 3.

Tenicroa nana was described by Snijman (1985) from the Kamiesberg in South Africa. In the protologue, the only date that appears in the selection of the type is: "fl. ex Kirstenbosch 26 Nov. 1980", and the leaves are described as "hysteranthous or present at flowering". However, the labels of both the holotype (NBG0123648-0) and the isotype (PRE0665215-0; http://plants .jstor.org/specimen/pre0665215-0) show the annotations "Fl. ex hort 1980-11-26" and "Bulbs 1980-06-10". The holotype includes several fragments: (1) three leafy bulbs; (2) two gatherings of leaves; (3) five unconnected inflorescences, and (4) an envelope containing three infructescences with ripe capsules and seeds.

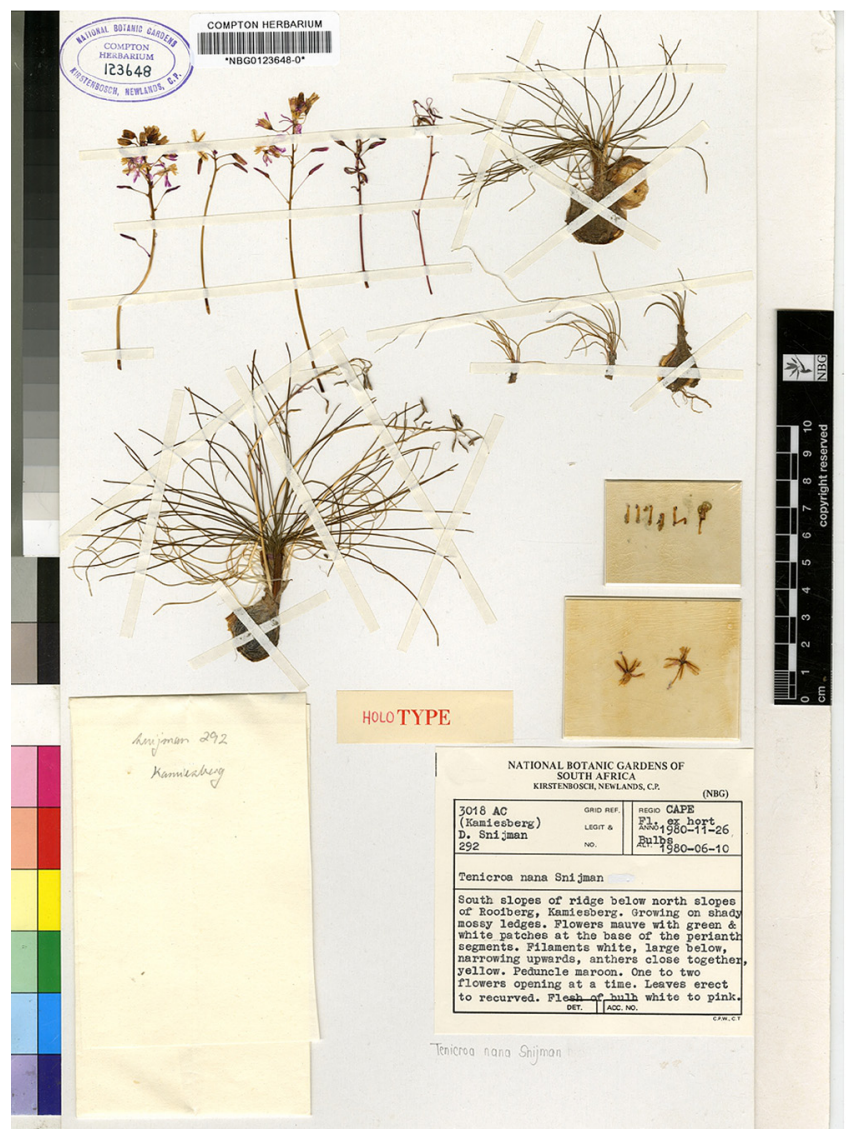

Fig. 3. Holotype of Tenicroa nana Snijman (NBG0123648-0): South Africa, Cape Province, Kamiesberg, on slopes of the Rooiberg, 1300 m, fl. ex Kirstenbosch 26 Nov 1980, D. Snijman 292.
Since the leaves are said to be "hysteranthous or synanthous" it is not possible to establish whether they were harvested at one time or not. Since no clear indication of that appears on the label, the collector only indicates that the bulbs were collected "198006-10" and flowered "1980-11-26", the type sheet could have been prepared from samples collected at one time from cultivated material and having leaves, flowers and fruits together. Therefore we suggest accepting the publication of this species as valid.

Drimia occultans G.Will. in Cact. Succ. J. (Los Angeles) 83: 287. 2012 - Holotype: NAMIBIA. Southern Namib Desert, flowered in Cape Town March 2011, G.F. Williamson 5929 (NBG barcode NBG0271283-0!). — For image of holotype, see Fig. 4.

Drimia occultans was described by Williamson (2011) from the southern Namib Desert. In the protologue, no collection date was indicated for the type but in the description it was said: "Leaf [...], lost in summer; Flowering peduncle appearing after leaves have withered and lost, [...] up to $55 \mathrm{~mm}$ in cultivation". Also under the cultivation remarks it was commented: "The first collection from Swartkop Hill was made in March 1994, with a single immature flower. The plants flowered in Feb. 1998, Jan. 2003, Jan. 2006 with the original collection still alive in August 2011". Moreover, the illustration of this species in the

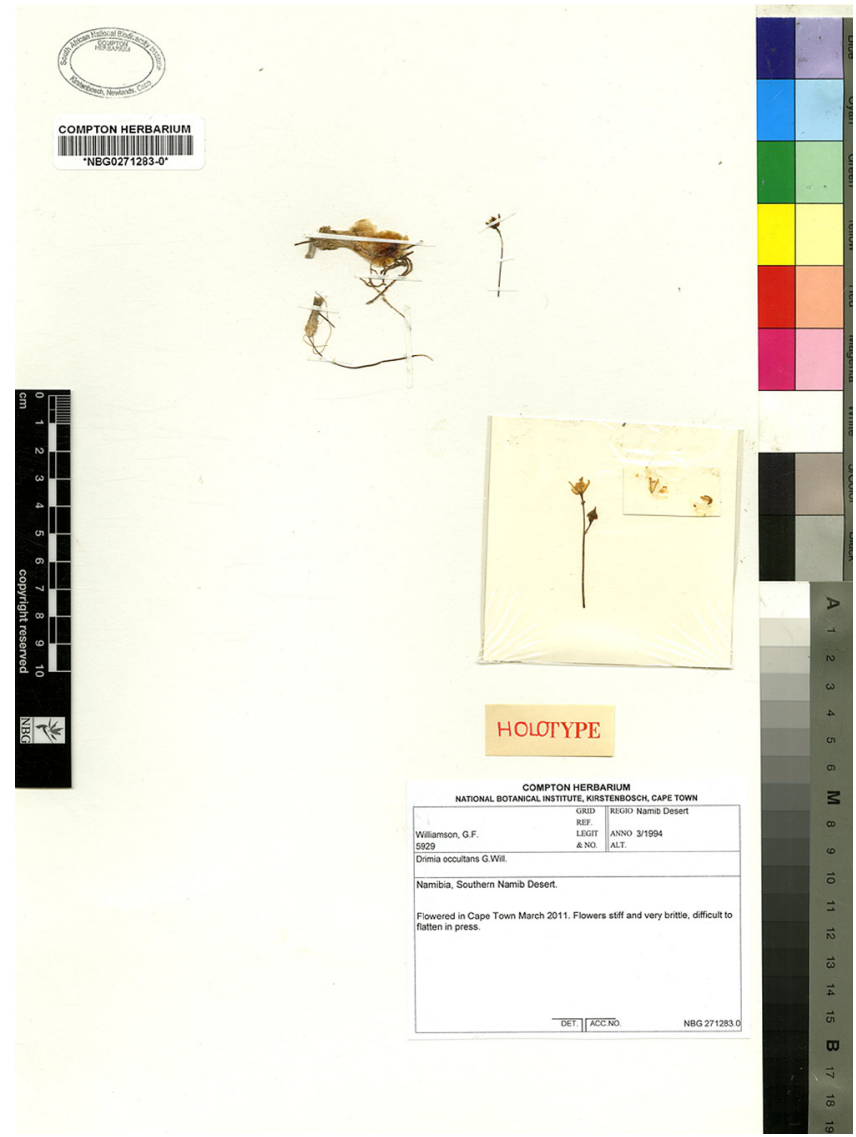

Fig. 4. Holotype of Drimia occultans G.Will. (NBG0271283-0): Namibia, Southern Namib Desert, Flowered in Cape Town March 2011, G. Williamson 5929. 
protologue shows one bulb bearing a single leaf, and a different bulb lacking leaves with a peduncle and one fruit, as well as details of several floral pieces, a capsule and two seeds, the legend showing "All from G. Williamson ex. hort., Feb. 1998, 5929 (NBG, WIND specimen lost)". The holotype (NBG0271283-0) confirms the protologue, and also provides further information. On the label of the G.F. Williamson 5929 collection it is said "Namibia, Southern Namib Desert", "3/1994" and "Flowered in Cape Town March 2011". Furthermore, the herbarium collection includes several fragments: (1) one bulb with a short portion of a leaf; (2) a bulb neck with a longer leaf; (3) two unconnected inflorescences, one of them with a flower and an immature capsule; and (4) a dissection of one flower. From the data shown above, the most plausible explanation is that the bulbs with fresh leaves were collected at a different time from the flowers. However, according to the legend of the original illustration, it is possible that all materials would have been available at the same time, and therefore the fragments in the holotype would correspond to a single collection made at one time in March 2011. Therefore, we regard this species name as validly published.

\section{ACKNOWLEDGEMENTS}

Anthony P. Dold (Selmar Schonland Herbarium, Rhodes University, Grahamstown, ZA) made helpful suggestions that improved the manuscript. Katherine Challis (Royal Botanic Gardens, Kew) kindly informed us about invalid publication of Drimia cochlearis, as shown in IPNI. Ronell R. Klopper (PRE) and Christopher Cupido (NBG) are thanked for sending images of type specimens.

\section{LITERATURE CITED}

APG (Angiosperm Phylogeny Group) 2003. An update of the Angiosperm Phylogeny Group classification for the orders and families of flowering plants: APG II. Bot. J. Linn. Soc. 141: 399-436. http://dx.doi.org/10.1046/j.1095-8339.2003.t01-1-00158.x

Chase, M.W., Reveal, J.L. \& Fay, M.F. 2009. A subfamilial classification for the expanded asparagalean families, Amaryllidaceae, Asparagaceae and Xanthorrhoeaceae. Bot. J. Linn. Soc. 161: 132136. http://dx.doi.org/10.1111/j.1095-8339.2009.00999.x

Dold, A.P. \& Brink, E. 2006. Drimia montana (Urgineoideae), a new species from Eastern Cape, South Africa. Bothalia 36(1): 64-66.

Hilliard, O.M. \& Burtt, B.L. 1985. Notes on some plants of southern Africa chiefly from Natal: XI. Notes Roy. Bot. Gard. Edinburgh 42: $227-260$.

Manning, J.C. \& Goldblatt, P. 2007. New species of Drimia (Hyacinthaceae: Urgineoideae) allied to Drimia marginata from Western and Northern Cape, South Africa. Bothalia 37(2): 183-187.

Manning, J.C., Martínez-Azorín, M. \& Crespo, M.B. 2007. A revision of Ornithogalum subgenus Aspasia section Aspasia, the chincherinchees (Hyacinthaceae). Bothalia 37(2): 133-164.

Martínez-Azorín, M., Crespo, M.B. \& Juan, A. 2007. Taxonomic revision of Ornithogalum subg. Cathissa (Salisb.) Baker (Hyacinthaceae). Anales Jard. Bot. Madrid 64: 7-25.
Martínez-Azorín, M., Crespo, M.B. \& Juan, A. 2010a. Taxonomic revision of Ornithogalum subg. Beryllis (Hyacinthaceae) in the Iberian Peninsula and the Balearic Islands. Belg. J. Bot. 142: 139-161.

Martínez-Azorín, M., Crespo, M.B. \& Juan, A. 2010b. Taxonomic revision of Ornithogalum subg. Ornithogalum (Hyacinthaceae) in the Iberian Peninsula and the Balearic Islands. Pl. Syst. Evol. 289: 181-211. http://dx.doi.org/10.1007/s00606-010-0343-9

Martínez-Azorín, M., Crespo, M.B., Juan, A. \& Fay, M.F. 2011. Molecular phylogenetics of subfamily Ornithogaloideae (Hyacinthaceae) based on nuclear and plastid DNA regions, including a new taxonomic arrangement. Ann. Bot. (Oxford) 107: 1-37. http://dx.doi.org/10.1093/aob/mcq207

Martínez-Azorín, M., Crespo, M.B. \& Dold, A.P. 2013a. Drimia cochlearis (Hyacinthaceae), a new species from South Africa. Syst. Bot. 38: 332-338. http://dx.doi.org/10.1600/036364413X666831

Martínez-Azorín, M., Crespo, M.B., Dold A.P., Westchnig, W., Pinter, M., Pfosser, M. \& Van Jaarsveld, E. 2013b. Sagittanthera (Hyacinthaceae, Urgineoideae), a new buzz pollinated genus from the Eastern Cape Province of South Africa. Phytotaxa 98: 43-54. http://dx.doi.org/10.11646/phytotaxa.98.2.2

McNeill, J., Barrie, F.R., Buck, W.R., Demoulin, V., Greuter, W., Hawksworth, D.L., Herendeen, P.S., Knapp, S., Marhold, K., Prado, J., Prud'homme van Reine, W.F., Smith, G.F., Wiersema, J.H. \& Turland, N.J. (eds.) 2012. International Code of Nomenclature for algae, fungi, and plants (Melbourne Code): Adopted by the Eighteenth International Botanical Congress Melbourne, Australia, July 2011. Regnum Vegetabile 154. Königstein: Koeltz Scientific Books.

Müller-Doblies, U. 1994. Enumeratio Albucarum (Hyacinthaceae) Austro-Africanarum adhuc cognitarum. 1. Subgenus Albuca. Feddes Repert. 105: 365-368. http://dx.doi.org/10.1002/fedr.19941050515

Müller-Doblies, U. 2006. Enumeratio Albucarum (Hyacinthaceae) Austro-Africanarum adhuc cognitarum. 3. Additions and additional notes to Albuca subgenus. Falconera and A. subgenus Albuca. Feddes Repert. 117: 96-138. http://dx.doi.org/10.1002/fedr.200611089

Müller-Doblies, U. \& Müller-Doblies, D. 1996. Revisionula incompleta Ornithogalorum Austro-Africanorum (Hyacinthaceae). Feddes Repert. 107: 361-548. http://dx.doi.org/10.1002/fedr.19961070511

Nordenstam, B. 1970. Studies in South African Liliaceae. III. The genus Rhadamanthus. Bot. Not. 123: 155-182.

Obermeyer, A.A. 1978. Ornithogalum: A revision of the southern African species. Bothalia 12: 323-376.

Obermeyer, A.A. 1980. A new subgenus Rhadamanthopsis and two new species of Rhadamanthus. Bothalia 13: 137-139.

Röpert, D. (ed.) 2000. Digital specimen images at the Herbarium Berolinense. http://ww2.bgbm.org/herbarium/default.cfm (continuously updated; accessed Oct 2013).

Rowley, G.D. 1975. A new succulent Albuca (Liliaceae). Ashingtonia 2: $55-56$.

Snijman, D.A. 1985. A new species of Tenicroa (Liliaceae-Scillae) from Namaqualand. S. African J. Bot. 51: 284-286.

Snijman, D.A., Manning, J.C. \& Goldblatt, P. 1999. A new Rhadamanthus species (Hyacinthaceae) from the Northwestern Cape, South Africa. Novon 9: 111-113. http://dx.doi.org/10.2307/3392134

Speta, F. 2001. Die Echte und die Falsche Meerzwiebel: Charybdis Speta und Stellarioides Medicus (Hyacinthaceae), mit Neubeschreibungen und Neukombinationen im Anhang. Stapfia 75: 139-176.

Williamson, G. 2011. A new Drimia sp. from the Namib Desert in Namibia. Cact. Succ. J. (Los Angeles) 83: 286-289. http://dx.doi.org/10.2985/0007-9367-83.6.286 